\title{
PENINGKATAN HASIL BELAJAR PKN MATERI INTEGRASI NASIONAL DALAM BINGKAI BHINNEKA TUNGGAL IKA MELALUI PENERAPAN MODEL PEMBELAJARAN KOOPERATIF TIPE JIGSAW PADA SISWA KELAS X DPIB-B SMK NEGERI 5 BANJARMASIN SEMESTER 2 TAHUN PELAJARAN 2017/2018
}

\author{
Yusliani \\ E-mail:yusliani@gmail.com \\ SMK Negeri 5 Banjarmasin
}

\begin{abstract}
Penelitian tindakan kelas dengan menggunakan metode strategi belajar Kooperatif tipe jigsaw dalam menyampaikan materi Integrasi Nasional dalam Bingkai Bhinneka Tunggal Ika,dapat meningkatkan aktivitas dan hasil belajar PKN siswa Kelas $X$ DPIB-BSMK Negeri 5 Banjarmasin, dengan jumlah siswa sebanyak 36 siswa, penilitian tindakan kelas ini untuk mengukur hasil ulangan dan aktivitas siswa penelitian tidakan kelas ini dilaksanakan pada semester 2 tahun pelajaran 2017/2018 Berdasarkan hasil tindakan kelas yang dilakukan melalui siklus I dan II, maka dapat dikatakan bahwa hasil sementara penelitian tindakan kelas mengunakan model pembelajaran kooperatif tipe jigsawpada materi Integrasi Nasional dalam Bingkai Bhinneka Tunggal Ikadapat meningkatkan hasil belajar dan aktivitas pada pelajaran PKN siswa Kelas X DPIB-BSMK Negeri 5 Banjarmasin telah menunjukkan kondisi awal untuk hasil belajar siswa yang tuntas 9 Orang (25\%) yang belum tuntas 27 orang (75\%) hasil observasi keaktifan siswa siswa tuntas 12 Orang $(33,33 \%)$, setelah dilaksanakan tindakan, siklus I hasil belajar siswa menunjukkan peningkakatan yaitu siswa yang tuntas 18 orang $(50 \%)$ belum tuntas 18 orang $(50 \%)$, untuk keaktifan siswa yang tuntas 23 Orang $(63,89 \%)$ belum tuntas 13 orang $(36 \%)$, pada siklus II nilai ulangan siswa yang tuntas 32 Orang $(88 \%)$ belum tuntas 4 Orang $(11,11 \%)$ untuk keaktifan siswa tuntas 35 Orang $(97,22 \%)$ atas temuan tersebut Penelitian Tindakan Kelas (PTK) yang dilakukan dengan menggunakan metode pembelajaran Jig Saw telah berhasil meningkatkan hasil ulangan dan keaktifan siswa. Simpulan hasil penelitian menggunakan metode pembelajaran tipe Jigsawdapat meningkatkan hasil ulangan dan keaktifan dalam pembelajaran PKn pada materi Integritas Nasional dalam bingkai Bhineka Tunggal Ika untuk siswa Kelas X DPIB-BSMKN 5 Banjarmasin.
\end{abstract}

Kata Kunci : Model Pembelajaran, Kooperatif, Jigsaw 


\section{PENDAHULUAN}

Pada pembelajaran PKNselama ini masih menggunakan metode ceramah, hafalan dan terkadang tanya jawab, kondisi pembelajaran yang terus menerus seperti itu membuat siswa tidak mampu mencapai kompetensi yang seharusnya dicapai. Siswa akan cenderung bosan dan jenuh dengan rutinitas yang itu-itu saja, tidak ada sesuatu yang bisa membuat mereka antusias terhadap pelajaran. Hal ini jelas dapat menghambat siswa dalam mengeksplorasi dirinya, menghambat mereka dalam menuangkan kreatifitasnya, dan masih banyak kerugian-kerugian yang lain yang dapat menghambat pertumbuhan kognitif, psikomotorik, dan afektif siswa, maka metode jigsaw dalam menyampaikan materi Integrasi Nasional dalam Bingkai Bhinneka Tunggal Ika, tujuan dari pembelajaran itu pada intinya adalah mencapai kompetensi yang telah ditetapkan, Menurut Djamarah (2008: 38) aktivitas artinya kegiatan atau keaktifan, jadi segala sesuatu yang dilakukan atau kegiatan-kegiatan yang terjadi baik fisik maupun non-fisik, merupakan suatu aktivitas, Menurut Sardiman (2011: 22) belajar adalah merupakan suatu proses interaksi antara diri manusia dengan lingkungannya yang mungkin berwujud pribadi, fakta, konsep ataupun teori. penulis dari Jombang (dalam Asmani, 2010:211) yang menyatakan bahwa guru yang baik adalah guru yang sedikit bicara banyak diamnya. Maksud dari pernyataan tersebut adalah guru hanya sebagai fasilitator saja sedangkan siswa yang harus aktif melakukan berbagai aktivitas dalam proses pembelajaran dengan melakukan diskusi, kerja kelompok, debat, bertanya dan lempar gagasan.

Pengertian Hasil Belajar(Sudjana, 2005:19). Hasil belajar berkenaan dengan kemampuan siswa di dalam memahami materi pelajaran, berdasarkan Taksonomi Bloom, hasil belajar dalam rangka pembelajaran meliputi tiga kategori ranah, yaitu: Ranah kognitif, berkenaan dengan hasil belajar intelektual yang terdiri dari enam aspek, yaitu: a). Pengetahuan (C.1) b). Pemahaman (C. 2) c). Penerapan (C. 3) d). Analisis (C. 4) e). Sintesis (C. 5) f). Evaluasi (C. 6).

Ranah afektif, berkenaan dengan sikap dan nilai. Ranah afektif meliputi lima jenjang kemampuan, yaitu: a). Menerima b). Menjawab/ Reaksi d). Karakteristik dengan suatu 
nilai e). Kompleks Nilai, Ranah psikomotor, meliputi: a). Keterampilan motorik b). Manipulasi benda-benda c). Koordinasi neuromuscular (menghubungkan, mengintai) Tipe hasil belajar kognitif lebih dominan daripada afektif dan psikomotor karena lebih menonjol namun hasil belajar psikomotor dan afektif harus menjadi bagian dari Pembelajaran Kooperatif Tipe Jigsaw

Pengertian Pembelajaran Kooperatif Tipe Jigsawa dalah salah satu strategi pembelajaran kooperatif di mana pembelajaran tersebut melalui penggunaan kelompok kecil siswa yang bekerja sama dalam memaksimalkan kondisi belajar untuk mencari tujuan pembelajaran dan mendapatkan pengalaman belajar yang maksimal, baik pengalaman individu maupun pengalaman kelompok. hasil penilaian dan proses pembelajaran di sekolah.

\section{METODE PENELITIAN}

Penelitian tindakan kelas ini merupakan ragam penelitian pembelajaran yang berkonteks kelas yang dilaksanakan oleh guru, memperbaiki mutu dan hasil pembelajaran dan mencobahal-hal baru dalam pembelajaran demi peningkatan mutu dan hasil pembelajaran.

Subjek penelitian tindakan kelas ini dilaksanakan pada semester 2 tahun pelajaran 2017/2018 pada siswa Kelas X DPIB-BSMK Negeri 5 Banjarmasin, dengan jumlah siswa sebanyak 36 Orang

Jenis data yang disajikan dalam penelitian ini adalah data Kuantitatif dan kualitatif, terdiri dari (1) lembar tes hasil belajar siswa dan (2) lembar observasi keaktifan siswa dalam mengikuti pembelajaran PKn pada siswa Kelas X DPIB-BSMK Negeri 5 Banjarmasin, data hasil ulangan siswa diambil dari hasil ulangan siswa setelah mengikuti pembelajara, sementara hasil keaktifan siswa diperoleh dari hasil observasi guru terhadap siswa selama mengikuti pembelajaran, pada masing-masing pertemuan atau siklus dilaksanakan refleksi tindakan. Analisis hasil penelitian digunakan indikator keberhasilan penelitian tindakan kelas ini adalah apabila hasil belajar siswa dapat mencapai ketuntasan Individual dan klasikal, ketuntasan 
individual jika siswa mencapai nilai $\geq 70$ dan ketuntasan klasikal jika seluruh siswa mencapai $\geq 85 \%$

Pelaksanaan tindakan kelas dilakukan melalui siklus 1 dengan 1 kali peremuan dan siklus kedua 1 kali pertemuan, penelitian ini dilaksanakan selama 3 bulan, yaitu dari Bulan Januari 2018 sampai dengan bulan Maret 2018, pada pembelajaran PKn materi Integritas Nasional dalam bingkai Bhineka Tunggal Ika. Adapun yang menjadi sasaran penelitian adalah hasil belajar siswa dan keaktifan siswa selama mengikuti pembelajaran.

Rancangan penelitian yang digunakan adalah Penelitian Tindakan Kelas sistem spiral dengan model Hopkins

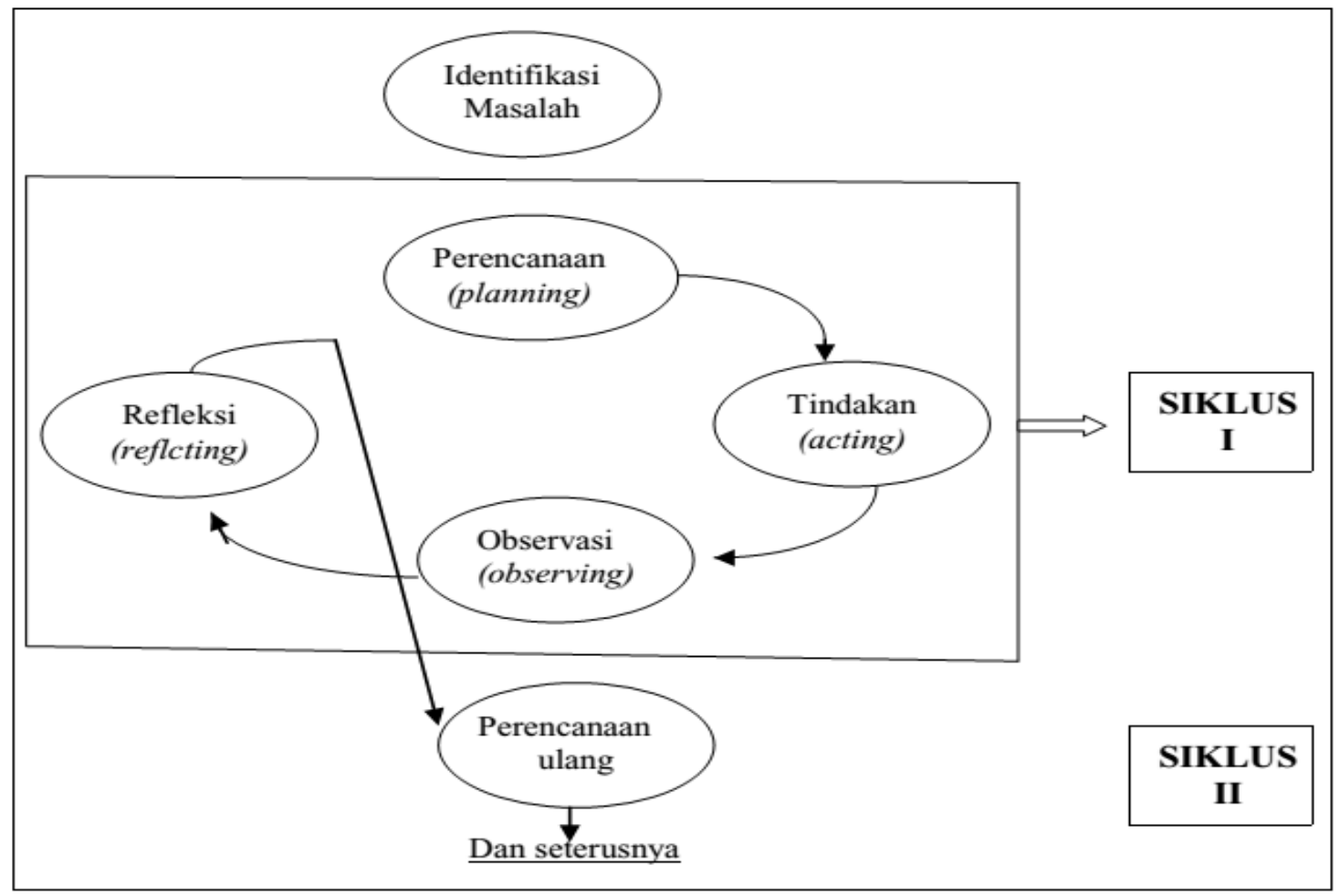

\section{HASIL PENELITIAN DAN PEMBAHASAN}

Deskripsi Kondisi Awal

Data awal berdasarkan hasil ulangan dan onservasi selama pembelajaran adalah sebagai berikut: 
Tabel 1 Rekapitulasi Nilai Ulangan Pembelajaran pada Kondisi Awal

\begin{tabular}{clcc}
\hline \multirow{2}{*}{ No } & \multirow{2}{*}{ Kriteria Ketuntasan } & \multicolumn{2}{c}{ Kondisi Awal } \\
\cline { 3 - 4 } & & Jumlah & $\%$ \\
\hline $\mathbf{1}$ & Tuntas & 9 & 25.00 \\
2 & Belum Tuntas & 27 & 75.00 \\
\hline \multirow{2}{*}{} & Jumlah & 36 & $\mathbf{1 0 0}$ \\
& Nilai terendah & & 50.00 \\
& Nilai tertinggi & & $\mathbf{9 0 . 0 0}$ \\
& Rata - rata & & $\mathbf{6 5 . 8 3}$ \\
& Ketuntasan & \multicolumn{2}{c}{$\mathbf{2 5 . 0 0}$} \\
\hline
\end{tabular}

Dari penjelasan tabel di atas dapat disimpulkan bahwa hasil observasi awal kelas hanya 9 orang yang mendapat nilai nilai $>75$ atau sekitar 25,00\% yang mencapai Kriteria Ketuntasan Minimal (KKM), sedangkan 27 orang atau sekitar 75,00\% yang belum mencapai KKM.

Tabel 2 Rekapitulasi Hasil Observasi Aktivitas Siswa pada Kondisi Awal

\begin{tabular}{llrr}
\hline No & \multicolumn{1}{c}{ Uraian } & Jumlah & Ket \\
\hline $\mathbf{1}$ & Siswa Tuntas & 12 & \\
$\mathbf{2}$ & Persentase Tuntas & 33.33 & \\
$\mathbf{3}$ & Siswa Belum Tuntas & 24 & \\
$\mathbf{4}$ & Persentase Belum Tuntas & 66.67 & \\
$\mathbf{5}$ & Ketuntasan Klasikal & 33.33 \\
\hline
\end{tabular}

Dari tabel di atas dapat disimpulkan bahwa dari 36 siswa terdapat 12 orang yang tuntas belajar (33,33\%) dilihat dari aktivitas belajar, sedangkan 24 siswa $(66,67 \%)$ belum tuntas dilihat dari aktivitas belajar.

1. Deskripsi Siklus 1

Hasil pelaksanaan tindakan pembelajaran PKn dengan menerapkan penggunaanmodel pembelajaran tipe jigsaw pada siklus pertama sebagaimana diuraikan di bawah ini : 
a. Hasil ulangan

Tabel 3 Rekapitulasi Nilai Ulangan Pembelajaran PKn pada Siklus I

\begin{tabular}{llcc}
\hline \multirow{2}{*}{ No } & \multirow{2}{*}{ Kriteria Ketuntasan } & \multicolumn{2}{c}{ Kondisi Awal } \\
\cline { 3 - 4 } & & Jumlah & $\%$ \\
\hline $\mathbf{1}$ & Tuntas & 18 & 50.00 \\
2 & Belum Tuntas & 18 & 50.00 \\
\hline \multirow{2}{*}{ Jumlah } & 36 & $\mathbf{1 0 0}$ \\
& Nilai terendah & & $\mathbf{6 0 . 0 0}$ \\
Nilai tertinggi & & $\mathbf{9 0 . 0 0}$ \\
Rata - rata & \multicolumn{2}{c}{$\mathbf{7 3 . 8 2}$} \\
Ketuntasan & \multicolumn{2}{c}{$\mathbf{5 0 . 0 0}$} \\
\hline
\end{tabular}

Tabel 4. Rekapitulasi Peningkatan Aktivitas Belajar Siswa pada Siklus I

\begin{tabular}{llrr}
\hline No & \multicolumn{1}{c}{ Uraian } & Jumlah & Ket \\
\hline $\mathbf{1}$ & Siswa Tuntas & 23 & \\
$\mathbf{2}$ & Persentase Tuntas & 63.89 & \\
$\mathbf{3}$ & Siswa Belum Tuntas & 13 & \\
$\mathbf{4}$ & Persentase Belum Tuntas & 36.11 & \\
$\mathbf{5}$ & Ketuntasan Klasikal & 63.89 & \\
\hline
\end{tabular}

Dari tabel di atas dapat disimpulkan bahwa dari 36 siswa terdapat 23 orang yang tuntas belajar $(63,89 \%)$ dilihat dari aktivitas belajar, sedangkan 13 siswa $(36,11 \%)$ belum tuntas dilihat dari aktivitas belajar. Melihat hasil di atas maka peneliti bersamasama dengan teman sejawat sepakat untuk melaksanakan perbaikan pembelajaran pada siklus II dengan harapan pada siklus II aktivitas belajarsiswa dapat mencapai perolehan di atas $85 \%$ sesuai dengan indikator dan kriteria keberhasilan yang telah ditetapkan.

Hasil pelaksanaan tindakan pembelajaran PKn dengan menerapkan penggunaan model pembelajaran tipe jigsaw pada siklus kedua sebagaimana diuraikan di bawah ini: 
Tabel 5 Rekapitulasi Nilai Ulangan Pembelajaran PKn pada Siklus II

\begin{tabular}{|c|c|c|c|}
\hline \multirow{2}{*}{ No } & \multirow{2}{*}{ Kriteria Ketuntasan } & \multicolumn{2}{|c|}{ Kondisi Awal } \\
\hline & & Jumlah & $\%$ \\
\hline 1 & Tuntas & 32 & 88.89 \\
\hline 2 & Belum Tuntas & 4 & 11.11 \\
\hline & Jumlah & 36 & 100 \\
\hline & Nilai terendah & \multicolumn{2}{|c|}{70.00} \\
\hline & Nilai tertinggi & \multicolumn{2}{|c|}{100.00} \\
\hline & Rata - rata & \multicolumn{2}{|c|}{85.00} \\
\hline & Ketuntasan & \multicolumn{2}{|c|}{88.89} \\
\hline
\end{tabular}

Dari tabel di atas tentang Rekapitulasi Nilai Tes Formatif PembelajaranPKn pada Siklus II di atas dapat diterangkan sebagai berikut:

1) Nilai rata-rata hasil belajar pada pelaksanaan perbaikan pembelajaran siklus kedua sebesar 85,00 .

2) Jumlah siswa yang tuntas belajar sebanyak 32 siswa atau sebesar $88,89 \%$

3) Siswa yang belum tuntas belajar sebanyak 4 orang sebesar $11,11 \%$

Dari penjelasan sebagaimana tersebut di atas dapat disimpulkan bahwa hasil nilai tes formatif mengalami peningkatan dari siklus I. Melihat hasil-hasil proses pembelajaran tersebut, maka peneliti bersama-sama dengan teman sejawat menyimpulkan bahwa hasil tes hasil belajar menunjukkan hasil 85,00, yang berarti sudah melebihi KKM minimal 75, dengan jumlah siswa yang telah tuntas belajar sebanyak 32 siswa atau 88,89\%. Hal ini menunjukkan bahwa ketuntasan belajar juga telah mencapai kriteria keberhasilan sebesar $85 \%$ sehingga proses perbaikan pembelajaran dinyatakan berhasil dan tuntas pada pelaksanaan siklus II. 
Tabel 6 Rekapitulasi Peningkatan Aktivitas Belajar Siswa Pembelajaran

PKn pada Siklus II

\begin{tabular}{llrr}
\hline No & \multicolumn{1}{c}{ Uraian } & Jumlah & Ket \\
\hline $\mathbf{1}$ & Siswa Tuntas & 35 & \\
$\mathbf{2}$ & Persentase Tuntas & 97.22 & \\
$\mathbf{3}$ & Siswa Belum Tuntas & 1 & \\
$\mathbf{4}$ & Persentase Belum Tuntas & 2.78 \\
$\mathbf{5}$ & Ketuntasan Klasikal & 97.22 \\
\hline
\end{tabular}

Dari tabel di atas dapat disimpulkan bahwa dari 36 siswa terdapat 35 orang yang tuntas belajar $(97,22 \%)$ dilihat dari aktivitas belajarnya. Melihat hasil di atas maka peneliti bersama-sama dengan teman sejawat menyimpulkan bahwa hasil pengamatan terhadap peningkatan aktivitas belajar sudah mencapai angka di atas $85 \%$, sehingga proses perbaikan pembelajaran dinyatakan berhasil dan tuntas pada siklus II.

Tabel 7 Rekapitulasi Peningkatan Aktivitas belajar Siswa pada Pembelajaran PKn pada Studi Awal, Siklus I dan Siklus II

\begin{tabular}{lccccc}
\hline \multirow{2}{*}{ No } & \multirow{2}{*}{ Uraian } & \multicolumn{2}{c}{ Siswa Tuntas } & \multicolumn{2}{c}{ Siswa Belum Tuntas } \\
& & Frekuensi & $\mathbf{\%}$ & Frekuensi & \% \\
\hline $\mathbf{1}$ & Awal & 12 & 33.33 & 24 & 66.67 \\
$\mathbf{2}$ & Siklus I & 23 & 63.89 & 13 & 36.11 \\
$\mathbf{3}$ & Siklus II & 35 & 97.22 & 1 & 2.78
\end{tabular}

Dari data pada tabelrekapitulasi peningkatan aktivitas belajar siswa pada pembelajaran PKn pada studi awal, siklus I dan siklus IIdi atas dapat diperoleh keterangan sebagai berikut:

\section{a. Siswa tuntas dilihat dari aktivitas belajar}

1. Pada temuan awal, siswa tuntas dilihat dari aktivitas belajar sebanyak 12 siswa atau $33,33 \%$ dari 36 siswa.

2. Pada siklus I, siswa tuntas dilihat dari aktivitas belajar sebanyak 23 siswa atau $63,89 \%$ dari 36 siswa. 
3. Pada siklus II, siswa tuntas dilihat dari aktivitas belajar sebanyak 35 siswa atau $97,22 \%$ dari 36 siswa.

\section{b. Siswa yang belum tuntas dilihat dari aktivitas belajar}

1. Pada temuan awal, siswa belum tuntas dilihat dari aktivitas belajar sebanyak 24 siswa atau $66,67 \%$ dari 36 siswa.

2. Pada siklus I, siswa belum tuntas dilihat dari aktivitas belajar sebanyak 13 siswa atau $36,11 \%$ dari 36 siswa.

3. Pada siklus II, siswa belum tuntas dilihat dari aktivitas belajar sebanyak 1 siswa atau $2,78 \%$ dari 10 siswa

4. Secara jelas peningkatan aktivitas belajar siswa selama proses perbaikan pembelajaran sebagaimana dijelaskan pada gambar di bawah ini :

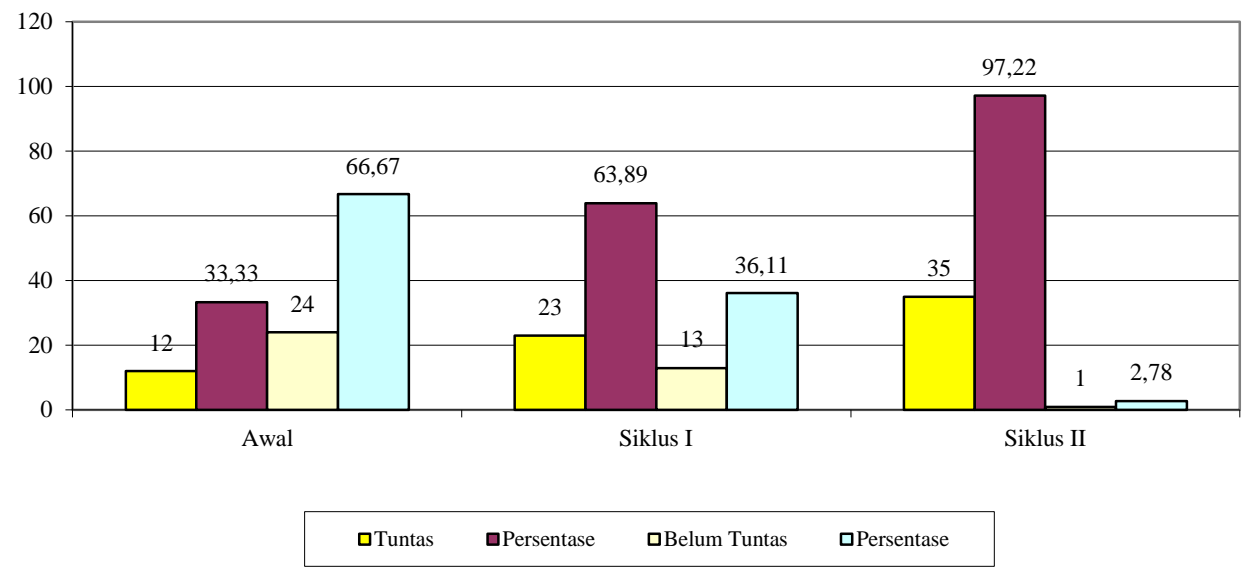

Gambar 4.1 Grafik Ketuntasan Siswa Berdasarkan Tingkat Aktivitas Belajar Siswa Pada Siklus I dan II

Tabel 8 Rekapitulasi Hasil belajar Siswa pada Pembelajaran PKn pada Studi Awal, Siklus I dan Siklus II

\begin{tabular}{|c|c|c|c|c|c|c|}
\hline \multirow{2}{*}{ No } & \multirow{2}{*}{ Uraian } & \multirow{2}{*}{$\begin{array}{l}\text { Nilai } \\
\text { Rata-2 }\end{array}$} & \multicolumn{2}{|c|}{ Siswa Tuntas } & \multicolumn{2}{|c|}{$\begin{array}{c}\text { Siswa Belum } \\
\text { Tuntas }\end{array}$} \\
\hline & & & Frekuensi & $\%$ & Frekuensi & $\%$ \\
\hline 1 & Awal & 65.83 & 9 & 25.00 & 27 & 75.00 \\
\hline 2 & Siklus I & 73.82 & 18 & 50.00 & 18 & 50.00 \\
\hline 3 & Siklus II & 85.00 & 32 & 88.89 & 4 & 11.11 \\
\hline
\end{tabular}


Dari tabel di atas dapat dijelaskan peningkatan nilai hasil dan ketuntasan belajar siswa

pada siklus I dan II secara terperinci sebagai berikut :

\section{1) Siswa Tuntas Belajar}

a) Pada temuan awal siswa yang tuntas sebanyak 9 siswa atau 25,00\% dari 36 siswa.

b) Pada siklus I siswa yang tuntas sebanyak 18 siswa atau $50,00 \%$ dari 36 siswa

c) Pada siklus II siswa yang tuntas sebanyak 32 siswa atau $88,89 \%$ dari 36 siswa

\section{2) Siswa Belum Tuntas Belajar}

a) Pada temuan awal siswa yang belum tuntas sebanyak 27 siswa atau $75,00 \%$ dari 36 siswa.

b) Pada siklus I siswa yang belum tuntas sebanyak 18 siswa atau 50,00\% dari 36 siswa

c) Pada siklus II siswa yang belum tuntas sebanyak 4 siswa atau $11.11 \%$ dari 36 siswa.

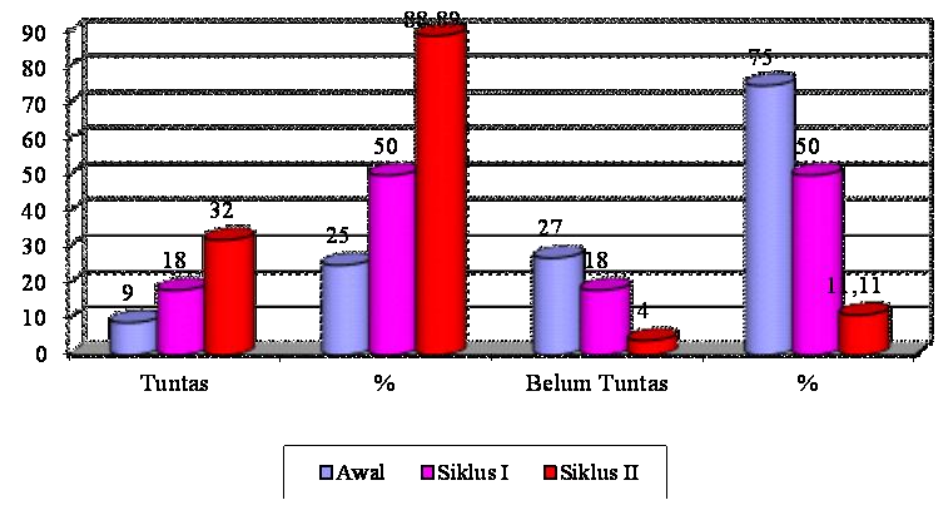

Gambar 4.2 . Grafik Peningkatan dan Penurunan Ketuntasan Belajar Siswa Siklus I dan II

Penjelasan mengenai peningkatan nilai rata-rata hasil belajar pada pembelajaran PKn dengan menggunakan model pembelajaran tipe jigsaw menunjukkan peningkatan yang cukup signifikan di mana pada kondisi awal sebesar 65,83 meningkat menjadi 73,82 pada siklus I dan pada akhir siklus II meningkat menjadi 85,00 Peningkatan nilai rata-rata hasil belajar siswa dalam bentuk grafik sebagaimana gambar di bawah ini : 


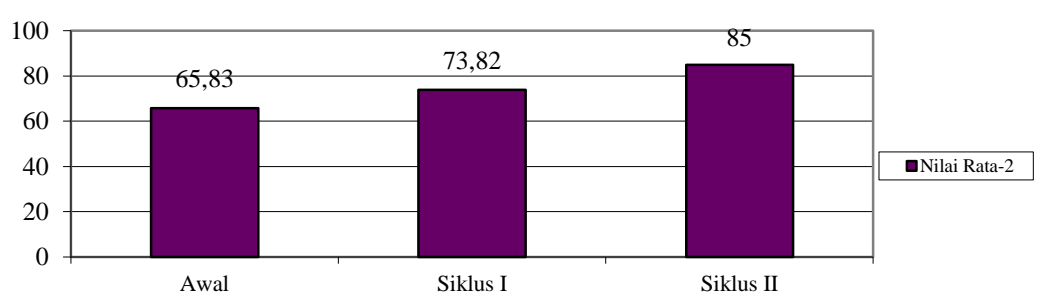

Gambar 4.3 Grafik Peningkatan Nilai Rata-rata Belajar Siswa Pada Kondisi Awal, Siklus I dan II

Dari hasil observasi mengenai hasil dan ketuntasan belajar siswa tersebut berdasarkan kriteria keberhasilan perbaikan pembelajaran dapat disimpulkan bahwa proses perbaikan pembelajaran dinyatakan berhasil karena peningkatan hasil dan ketuntasan belajar siswa mencapai angka $88,89 \%$ dari $85 \%$ batasan minimal yang telah ditentukan pada kriteria keberhasilan proses perbaikan pembelajaran.

\section{KESIMPULAN}

Penerapan model pembelajaran kooperatif tipe jigsaw pada Pembelajaran PKn materi Integrasi Nasional dalam Bingkai Bhinneka Tunggal Ika lebih baik daripada sebelum diterapkannya metode tersebut. Hal tersebut dibuktikan dengan adanya peningkatan aktivitas dan hasil belajar Pembelajaran PKn materi Integrasi Nasional dalam Bingkai Bhinneka Tunggal Ika. Selain itu, sebagian besar peserta didik tertarik dengan model pembelajaran kooperatif tipe jigsaw yang baru pertama mereka diterapkan sehingga mendorong untuk belajar secara menyenangkan dan tidak mudah bosan sehingga proses pembelajaran menjadi lebih menarik dan bermakna bagi para siswa.

\section{Saran}

Pembelajaran PKn materi Integrasi Nasional dalam Bingkai Bhinneka Tunggal Ika menggunakan pembelajaran model pembelajaran kooperatif Jigsawsehiungga pembelajaran dapat berjalan dengan baik, siswa dalam belajar berkelompok lebih aktif dan bersemangat, dan tugas yang diberikan oleh guru dapat terselesaikan dengan mudah, cepat dan guru hanya ber peran sebagai fasilitator yangbaik dalam kegiatan 
pembelajaran,selalu memantau aktifitas siswa, bagi sekolah diaharapkan mengoptimalan sarana dan prasarana serta penyediaan alat dan media sebagai penunjang yang mendukung pelaksanaan pembelajaran agar siswa lebih aktif dan termotivasi dalam penerapan tipe jigsaw.

\section{DAFTAR PUSTAKA}

Arikunto,S 2002. Posedur Penelitian. Suatu Pendekatan Praktek. Jakarta: PT Rineka Cipta.

Asmani, Jamal.2010. Buku Panduan Internalisasi Pendidikan Karakter. Sekolah. Jogjakarta: Diva Press

Corebima. A. Duran.2002.Pembelajaran Kooperatif, Jakarta: Depdikbud

Depdiknas. 2006 Permendiknas No. 22 Tahun 2006 TentangStandar Isi. JakartaDepdinas

Depdiknas.2005. Peraturan Pemerintah Republik Indonesia Nomor 19 tahun 2005 tentang Standar Nasional Pendidikan, Jakarta: Departemen Pendidikan Nasional

Dimiyati dan Mudjiono, 2002. Belajar dan Pembelajaran, Jakarta: Rineka Cipta

Dimiyati \& Mudjiono. 2004. Belajar dan Pembelajaran. Jakarta: Proyek Pembinaan dan Peningkatan Mutu Kependidikan, Dirjen Dikti Depdikbud

Hamalik, Oemar, 2007, Evaluasi Kurikulum Pendekatan Sistimatik, Bandung: Bumi Aksara

Herawati Susilo, Prof. Dra. Dkk. 2008, Penelitian Tindakan Kelas, Malang: Buyu Media. Publising

Heryanto, Imam, 2007, Membuat Database Dengan MS Office Access, Informatika , Bandung

Ibrahim, 2002. Pembelajaran Kooperatif, Universitas Press: UNESA Maleong Ibrahim, Muslimin dkk. 2001. Pembelajaran Kooperatif. Surabaya: UNESA Press

Ittihad, Zainul Amin. 2007. PendidikanKewarganegaraan. Universitas terbuka, Jakarta. $446 \mathrm{hlm}$

Lexy J. Moleong. 2002. Metode Penelitian Kualitatif Edisi Revisi. Bandung: PT Remaja Rosdakarya.

Nunnally, J.C. 1978. Psychometric Theory. McGraw.

Pemerintah Republik Indonesia, 2005, Peraturan Pemerintah Republik Indonesia No. 19 Tahun 2005 tentang Standar Nasional Pendidikan. Jakarta

Rindel D.W. 2009. Mediteranean Climate Ecosystem. Academi Press. San diego. LA

Ruminiati. 2007. Pengembangan Pendidikan Kewarganegaraan SD, Jakarta: Direktorat Jenderal Pendidikan Tinggi Departemen Pendidikan Nasional.

Segala, 2011. Teoi Belajar dan Pembelajaran, Bandung: Sinar Baru

Sardiman, AM. 2011. Interaksi dan Motivasi Belajar Mengajar. Jakarta: Raja Grafindo

Satori, Djamaan dan Aan Komariah. 2009, Metodologi Penelitian Kualitatif, Bandung: Alfabeta

Slavin, 2005. Strategi Belajar Menagajar, Depdikbud : Jakarta 
Slavin, Robert e. 2003. Coopefive Leaning Teori, Riset dan Praktik, Bandung: Nusa Media.

Sudjana. 2005. Metode Statistik. Tarsito. Bandung

Syaiful Bahri Djamarah. 2008. Psikologi Belajar. Jakarta: Rineka Cipta

Tarigan, 2008. Penerapan Pembelajaran Kooperatif, Malaka Pada Comprehensif: Suarabaya 